\title{
ANALISIS PENGARUH SUDUT DEADRISE PLANNING CRAFT TERHADAP STABILITAS DAN SEAKEEPING
}

\section{Analysis of the Effect of Deadrise Planning Craft Angle on Stability and Seakeeping}

\section{Erifive Pranatal $^{1, \text { a }}$}

${ }^{1}$ Institut Teknologi Adhi Tama Surabaya, Jl. Arief Rachman Hakim No 100, Surabaya, Jawa Timur, Indonesia

e-mail: ${ }^{a}$ erifive@itats.ac.id

Diterima : 12 Oktober 2020; Direvisi: 20 November 2020; Disetujui: 4 Januari 2021

\begin{abstract}
Abstrak
Perancang kapal berusaha untuk memperoleh stabilitas dan seakeeping yang baik terlebih untuk kapal cepat bertipe planning hull. Tipe ini memiliki deadrise sehingga lambungnya bentuk ' $\mathrm{V}$ ' sehingga tujuan penelitian ini adalah untuk mengetahui pengaruh besar sudut deadrise terhadap stabilitas dan seakeeping. Objek penelitian adalah kapal planning hull Series 62: parent model 4677-1. Metode penelitian menggunakan simulasi komputer dengan bantuan software dan perhitungan stabilitas tersebut dibandingkan dengan metode Krylov II. Hasil penelitian menyatakan bahwa tiga variasi deadrise yaitu $10^{\circ}, 13^{\circ}$, dan $18^{\circ}$, sudut deadrise yang kecil memberikan stabilitas yang baik tetapi mengurangi olah gerak kapal (seakeeping) sedangkan sudut deadrise yang besar akan mengurangi kemampuan stabilitas kapal tetapi memiliki seakeeping yang baik. Ketiga model tersebut sama-sama memenuhi regulasi stabilitas IMO. Sehingga besar sudut deadrise yang direkomendasikan untuk penelitian ini adalah $13^{\circ}$.
\end{abstract}

Kata kunci: planning hull; stabilitas; seakeeping

\section{Abstract}

Ship designer tries to get good stability and seakeeping, especially for the planning hulltype fast boats. This type has a deadrise so the hull ' $V$ ' shaped. Therefore the research purpose is to determine the effect the deadrise angle on ship stability and seakeeping. The object research is planning hullseries 62: parent model 4677-1. The research method uses computer simulation with software and its stability calculation is compared with the Krylov II method. The result of the research states that three variations of deadrise, namely $10^{\circ}, 13^{\circ}$, and $18^{\circ}$, the small deadrise angle provides good stability but reduces seakeeping while a large deadrise angle will reduce the stability but have good seakeeping. All models pass IMO regulations on stability. Therefore a deadrise angle of $13^{\circ}$ is recommended for this study.

Keywords: planning hull; stability; seakeeping

\section{PENDAHULUAN}

Tahapan desain kapal dimulai dari preliminary design. Tahap ini dilakukan perhitungan stabilitas awal dan seakeeping secara umum, sehingga diperoleh gambaran kapal secara cepat. Kapal didesain sedemikian rupa sehingga

(C) 2020 Wave: Jurnal Ilmiah Teknologi Maritim.This work is licensed under CC BY-NC-SA 4.0 
memiliki stabilitas dan seakeeping yang baik. Stabilitas kapal berhubungan dengan kelayakan dan keselamatan kapal dan muatan sedangkan seakeeping berkaitan dengan kenyamanan penumpang pada saat kapal beroperasi. Oleh karena itu baik stabilitas dan seekeeping harus memenuhi kriteria yang ditentukan organisasi kemaritiman, seperti IMO (International Maritime Organization) atau biro klasifikasi.

Kapal dengan tipe planning hull merupakan kapal dengan $\mathrm{Fn}_{\nabla}=1-3,5$. Tipe lambung kapal ini berbentuk "V" sehingga memiliki deadrise. Besarnya sudut deadrise pasti mempengaruhi performa kapal baik ditinjau dari tahanan kapal (Pranatal, 2020), stabilitas dan juga seakeeping. Pemilihan besar sudut deadrise yang tepat dapat menghasilkan stabilitas dan seakeeping yang baik. Sehingga tujuan penelitian ini adalah untuk mengetahui pengaruh variasi besar sudut deadrise terhadap stabilitas dan seakeeping kapal dengan tipe planning hull. Objek penelitian ini menggunakan model kapal planning hull Series 62: parent model 4677-1 dengan deadrise $13^{\circ}$. Untuk mengetahui pengaruh deadrise maka dilakukan variasi sudut deadrise di bawah dan di atas nilai sudut existing, yaitu sudut $10^{\circ}$ dan $18^{\circ}$. Oleh karena itu ada tiga variasi sudut deadrise yaitu $10^{\circ}, 13^{\circ}$, dan $18^{\circ}$, dengan dasar pemilihan bahwa sudut-sudut tersebut sudah mewaliki analisis pengaruh deadrise terhadap stabilitas dan seakeeping. Pembuatan model 3D tiap-tiap variasi dilakukan dengan displacement tetap.

Penelitian ini membahas stabilitas kapal ditinjau dari kriteria stabilitas kapal umum menurut regulasi IMO. Perhitungan stabilitas menggunakan bantuan software Maxsurf Stability dan dibandingkan dengan metode Krylov II. Sedangkan perhitungan seakeeping menggunakan bantuan software Maxsurft Ship Motion. Pada perhitungan seakeeping kapal membahas gerak kapal khususnya gerakan roll, pitch, dan heave. Data model lambung kapal yang digunakan adalah Series 62. Hasil penelitian yang diharapkan adalah penelitian ini memberikan informasi sudut deadrise yang paling optimal untuk keselamatan dan kenyamanan penumpang pada kapal planning hull, sudut deadrise yang kecil akan menghasilkan tahanan yang baik dan juga olah gerak kapal.

\section{TINJAUAN PUSTAKA}

Menurut Aryawan \& Putranto (2018) gerakan rolling dapat dikurangi dengan penambahan sponson pada sisi lebar kapal Aquaculture Fishing, dengan variasi perbandingan $\mathrm{L} / \mathrm{B}$, di mana $\mathrm{L} / \mathrm{B}=10$ menghasilkan damping coefficient yang baik. Sedangkan Putranto, dkk., (2016) melakukan penelitian variasi deadrise terhadap stabilitas. Variasi deadrise yang dipilih $6^{\circ}, 11^{\circ}$, dan $16^{\circ}$. Pada konsisi kapal muatan 100\% lengan pengembali paling besar dihasilkan oleh sudut deadrise terkecil yaitu $6^{\circ}$. Pada penelitian ini variasi sudut deadrise mempengaruhi displacement kapal.

Penelitian oleh Luhulima, dkk., (2014) adalah pemilihan tipe lambung kapal monohull, catamaran, dan trimaran untuk kapal penumpang ditinjau dari stabilitas dan seakeeping kapal. Hasil penelitian tersebut adalah kapal dengan tipe lambung multihull menghasilkan nilai BM, GM, GZ yang lebih baik dari kapal monohull, sedangkan karakteristik seakeeping seperti gerakan rolling, heaving dan pitching menunjukkan kapal monohull memiliki gerakan yang lebih baik dibanding multihull.

\section{Kajian Teori}

Kapal tipe lambung planning bekerja gaya tekan, $F_{P}$ dan gaya hidrostatik, $F_{H}$. Gaya tekan bekerja pada titik pusat gaya apung, sedangkan gaya tekan bekerja di sepanjang lambung kapal yang tercelup. Apabila kecepatan kapal meningkat, maka permukaan basah dan volume kapal akan berkurang dengan cepat, sehingga $F_{P}>F_{H}$. Tipe lambung ini biasa digunakan untuk kapal cepat dengan $\mathrm{Fn}_{\nabla}=$ 1-3,5 (Molland, et al., 2017). Data kapal tipe lambung planning single chine telah diteliti oleh (Blount \& Clement, 1963) dan diberi nama data lambung kapal planning hull Series 62. Body plan 
model lambung Series 62 dapat dilihat pada Gambar 1 berikut.

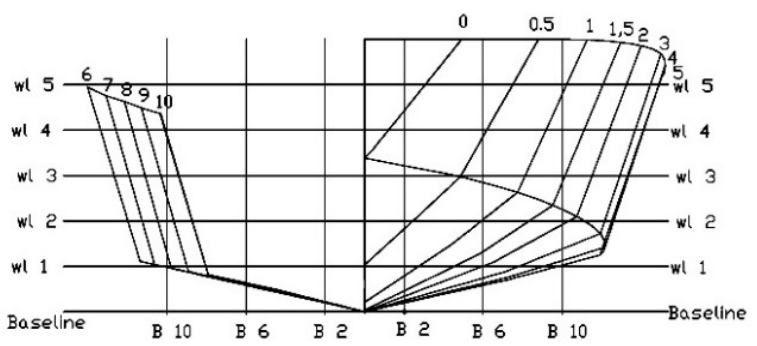

Gambar 1. Body plan planning hull Series 62

Tipe lambung ini memiliki deadrise, $\beta$ atau rice of floor (ROF). Di mana deadrise adalah sudut lambung dalam derajat yang diukur dari garis baseline, sudut pada lunas (keel) dan kemiringan dasar kapal. Pada data Series 62, sudut ini bernilai $13^{\circ}$.

\section{Stabilitas Kapal}

Istilah stabilitas lebih menunjukkan kecenderungan suatu body atau sistem kembali ke posisi awalnya setelah dia mengalami gangguan kecil (Rawson \& Tupper, 2001). Kapal dikatakan stabil apabila memenuhi semua kriteria yang telah ditentukan oleh badan yang berotoritas seperti IMO. Berikut adalah beberapa kriteria stabilitas kapal umum berdasarkan IMO:

Tabel 1. Kriteria stabilitas kapal berdasarkan IMO

\begin{tabular}{clcc}
\hline No. & \multicolumn{1}{c}{ Criteria } & Value & Units \\
\hline 1. & Area $0^{\circ}$ to $30^{\circ}$ & 0,055 & $\mathrm{~m} . \mathrm{rad}$ \\
\hline 2. & Area $0^{\circ}$ to $40^{\circ}$ & 0,090 & $\mathrm{~m} . \mathrm{rad}$ \\
\hline 3. & Area $30^{\circ}$ to $40^{\circ}$ & 0,030 & $\mathrm{~m} . \mathrm{rad}$ \\
\hline 4. & $\begin{array}{l}\text { Max } \mathrm{GZ} \text { at } 30^{\circ} \\
\text { or greater }\end{array}$ & 0,200 & $\mathrm{~m}$ \\
\hline 5. & $\begin{array}{l}\text { Angle of } \\
\text { maximum } \mathrm{GZ}\end{array}$ & 25 & $\mathrm{deg}$ \\
\hline 6. & Initial $\mathrm{GMt}$ & 0,150 & $\mathrm{~m}$ \\
\hline
\end{tabular}

Beberapa metode dilakukan untuk menghitung stabilitas kapal seperti metode Krylov dan Metode Barnhart \& Thewlis. Selain itu perhitungan stabilitas juga dapat dilakukan dengan bantuan software komersil perkapalan seperti Maxsurf Stability.
Perhitungan lengan stabilitas menurut Krylov membutuhkan jari-jari metasenter, $r_{\varphi}$ dan pada kondisi displacement tetap. Nilai lengan stabilitas, $\mathrm{l}=\mathrm{GZ}$ dapat dihitung menggunakan rumus persamaan (1) (Semyonov-Tyan-Shansky, 1966):

$$
l=l_{c}-a \sin \theta
$$

di mana:

$l_{c}$ : lengan stabilitas bentuk.

Lengan stabilitas bentuk dapat dihitung menggunakan persamaan (2) berikut:

$$
l_{c}=\cos \theta \int_{0}^{\theta} r_{\varphi} \cos \varphi d \varphi+\sin \theta \int_{0}^{\theta} r_{\varphi} \sin \varphi d \varphi
$$

di mana:

a : KG-KB;

$\theta$ : sudut kemiringan kapal.

\section{Seakeeping}

Istilah seakeeping digunakan untuk menunjukkan performa kapal seperti gerakan kapal pada gelombang, deck wetness, dan slamming (Rawson \& Tupper, 2001). Gerakan kapal pada gelombang adalah gerakan yang terjadi pada kapal ketika kapal tersebut berpapasan dengan gelombang air yang memiliki karakteristik dan arah tertentu. Hal ini sebagai respon kapal terhadap gelombang yang menghadang. Gerakan tersebut antara lain gerakan pitch, heave, dan roll. Deck wetness adalah keadaan di mana geladak kapal terkena air akibat gelombang yang menghantam kapal. Dalam mendesain kapal, hal ini harus dihindari karena dapat merusak peralatan dan mesin pada geladak. Slamming adalah fenomena yang terjadi apabila dasar haluan naik melewati permukaan gelombang dan kemudian masuk kembali ke dalam air dengan kecepatan relatif vertikal haluan dan menimbulkan hempasan. Gerakan slamming dapat menimbulkan kegagalan struktur kapal. Sugiyarto, dkk., (2016) melakukan penelitian tentang analisis tegangan pada kapal perang tipe corvette akibat beban slamming. Seakeeping berkaitan erat dengan kenyamanan operator dan penumpang kapal. Sehingga desain kapal harus diperhatikan terlebih untuk kapal cepat dan kapal perang. 
Gambar 2 dan Tabel 2 menjelaskan macam-macam gerakan kapal. Di mana gerakan rolling, pitching dan heaving yang dialami oleh kapal pada saat kapal dalam gelombang.

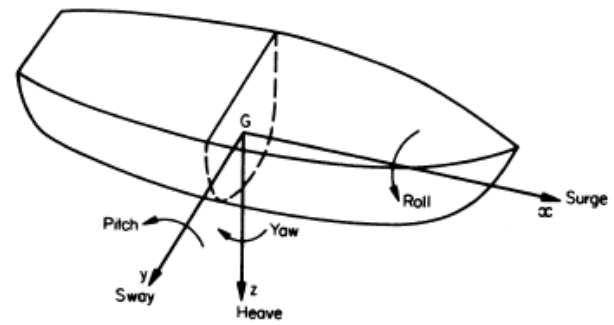

Gambar 2. Gerakan kapal

Tabel 2. Macam-macam gerakan kapal

\begin{tabular}{|c|c|c|c|}
\hline $\begin{array}{l}\text { Translation } \\
\text { or rotation }\end{array}$ & Axis & $\begin{array}{l}\text { Descrip- } \\
\text { tion }\end{array}$ & Positive sense \\
\hline \multirow{3}{*}{ Translation } & Along $x$ & Surge & \multirow{3}{*}{$\begin{array}{l}\text { Forwards to } \\
\text { starboard } \\
\text { downwards }\end{array}$} \\
\hline & Along y & Sway & \\
\hline & Along z & Heave & \\
\hline \multirow{3}{*}{ Rotation } & About $x$ & Roll & $\begin{array}{l}\text { Starboard side } \\
\text { down }\end{array}$ \\
\hline & About y & Pitch & Bow up \\
\hline & About z & Yaw & $\begin{array}{l}\text { Bow to } \\
\text { starboard }\end{array}$ \\
\hline
\end{tabular}

Berdasarkan hukum kedua Newton, persamaan gerak benda terapung dalam 6 derajat kebebasan dapat dituliskan pada persamaan (3).

$$
F=M a
$$

di mana:

$\mathrm{F}$ : resultan gaya pada benda terapung $(\mathrm{N}$ atau $\mathrm{kN}$ );

$\mathrm{M}$ : massa benda terapung ( $\mathrm{kg}$ atau tong);

A : percepatan $\left(\mathrm{m} / \mathrm{s}^{2)}\right.$.

Persamaan (3) dapat dituliskan dalam bentuk lain di mana kecepatan benda (a) adalah turunan kedua dari perpindahan benda terapung seperti pada persamaan (4).

$$
F=M \ddot{x}
$$

Sedangkan gaya yang bekerja pada benda terapung terdiri dari gaya inersia, gaya peredam, gaya restoring, dan gaya excitation.
Selain itu yang harus diperhatikan untuk menghitung seakeeping adalah sudut hadap atau heading angle. Sudut hadap adalah besar sudut yang dibentuk oleh arah gerakan kapal dan gelombang. Pengertian lebih lanjut dapat dilihat pada Gambar 3 berikut.

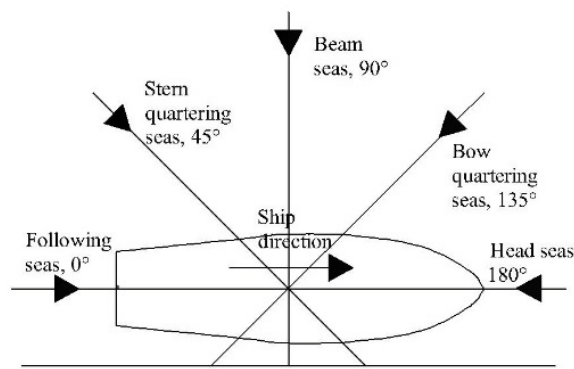

Gambar 3. Heading angle

Folowing seas disebut bila arah gelombang dan kapal membentuk sudut $0^{\circ}$ atau searah. Head seas, di mana arah datang gelombang dan kapal membentuk $180^{\circ}$ atau saling bertemu, demikian seterusnya untuk bow quartering seas, beam seas, stern quartering seas dan membentuk sudut antara arah kapal dan datangnya gelombang berturut-turut $45^{\circ}, 90^{\circ}$, dan $135^{\circ}$.

\section{Sea State}

Tabel 3. Skala Douglas

\begin{tabular}{ccc}
\hline $\begin{array}{c}\text { Douglas } \\
\text { Sea Scale } \\
\text { Degree }\end{array}$ & Height $(m)$ & Description \\
\hline 0 & No wave & Calm (glassy) \\
\hline 1 & $0,00-0,10$ & Calm (rippled) \\
\hline 2 & $0,10-0,50$ & Smooth \\
\hline 3 & $0,50-1,25$ & Slight \\
\hline 4 & $1,25-2,50$ & Moderate \\
\hline 5 & $2,50-4,00$ & Rough \\
\hline 6 & $4,00-6,00$ & Very rough \\
\hline 7 & $6,00-9,00$ & High \\
\hline 8 & $9,00-14,00$ & Very high \\
\hline 9 & $14,00+$ & Phenomenal \\
\hline
\end{tabular}




\section{Sea state digunakan untuk mengukur} keganasan laut pada saat tertentu. Sea state sering digunakan perancang kapal untuk mendesain kapal. Skala Douglas membagi keganasan laut ke dalam 10 tingkatan berdasarkan tinggi gelombang. Skala Douglas dapat dilihat pada Tabel 3.

\section{Response Amplitude Operator (RAO)}

RAO atau sering disebut juga sebagai transfer function adalah fungsi respon yang terjadi akibat gelombang dalam rentang frekuensi yang mengenai struktur offshore. RAO merupakan alat untuk mentransfer beban luar (gelombang) dalam bentuk respon suatu struktur. RAO dapat didefenisikan berdasarkan persamaan (5) berikut ini:

$$
R A O=\frac{X_{p}(\omega)}{\eta(\omega)}
$$

di mana:

$\mathrm{X}_{\mathrm{P}}(\omega)$ : amplitudo struktur apung;

$\eta(\omega) \quad$ : amplitudo gelombang.

\section{METODE PENELITIAN}

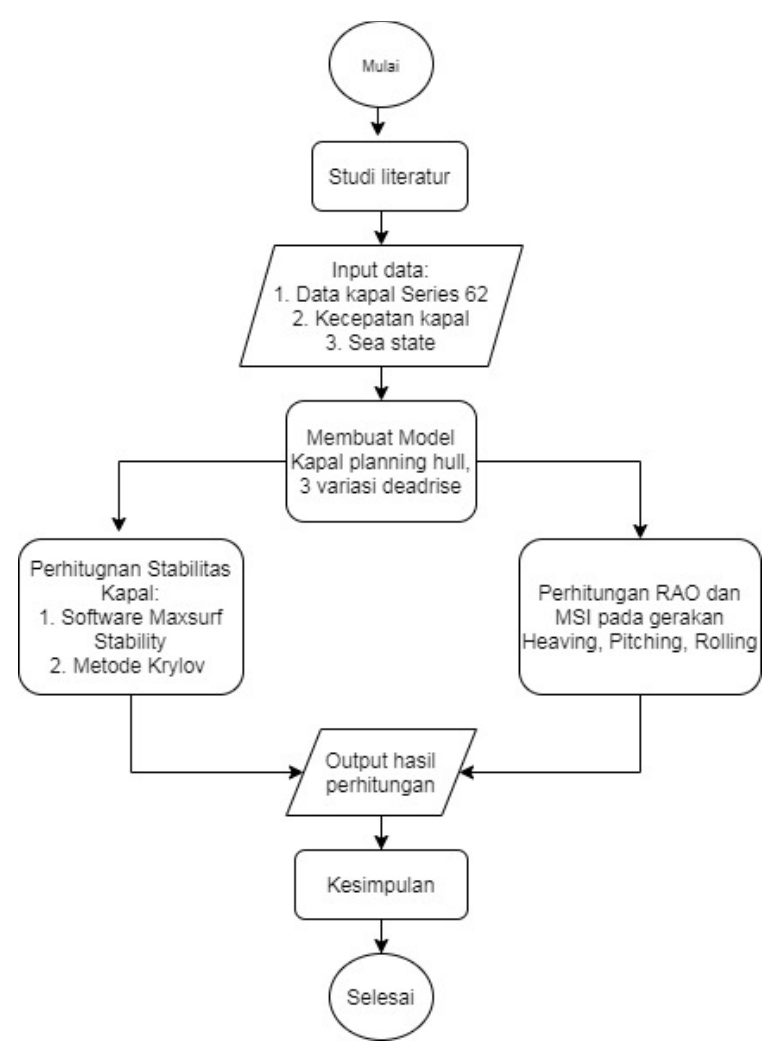

Gambar 4. Diagram alir penelitian

\section{Permasalahan dalam penelitian ini} diselesaikan dengan menggunakan diagram alir pada Gambar 4. Data yang diperlukan untuk penelitian ini adalah data kapal planning hull Series 62: parent model 4677-1 dengan deadrise $13^{\circ}$ di mana body plan dapat dilihat pada Gambar 1 . Sedangkan ukuran pokoknya dapat dilihat pada Tabel 4 berikut ini:

Tabel 4. Ukuran pokok Series 62: parent model 4677-1

\begin{tabular}{ccc}
\hline Item & Besaran & Satuan \\
\hline$\nabla$ & 79,500 & $\mathrm{~m}^{3}$ \\
\hline$\Delta$ & 81,500 & ton \\
\hline $\mathrm{S}$ & 138,671 & $\mathrm{~m}^{2}$ \\
\hline LWL & 23,845 & $\mathrm{~m}$ \\
\hline $\begin{array}{c}\text { Draft } \\
\text { amidship }\end{array}$ & 1,050 & $\mathrm{~m}$ \\
\hline Beam Max & 6,034 & $\mathrm{~m}$ \\
\hline VCG & 0,426 & $\mathrm{~m}$ \\
\hline LCG & 11,238 & $\mathrm{~m}$ \\
\hline Cb & 0,526 & - \\
\hline Cm & 0,651 & - \\
\hline B/Draft & 5,748 & - \\
\hline Ear & & \\
\hline
\end{tabular}

Kecepatan kapal pada analisis seakeeping dapat dilihat pada Tabel 5 berikut ini:

\begin{tabular}{ccc}
\multicolumn{3}{c}{ Tabel 5. Kecepatan kapal } \\
\hline $\mathrm{Fn}_{\nabla}$ & Kecepatan (V) & Satuan \\
\hline 1 & 13 & knot \\
\hline 2 & 25 & knot \\
\hline 3 & 38 & knot \\
\hline 4 & 50 & knot \\
\hline
\end{tabular}

Sea state yang digunakan pada penelitian ini adalah state satu, empat, dan lima dengan tinggi 
gelombang berturut-turut $0,1,1,5$, dan $3 \mathrm{~m}$. Tipe spektrum yang digunakan adalah satu Parameter Bretschneider.

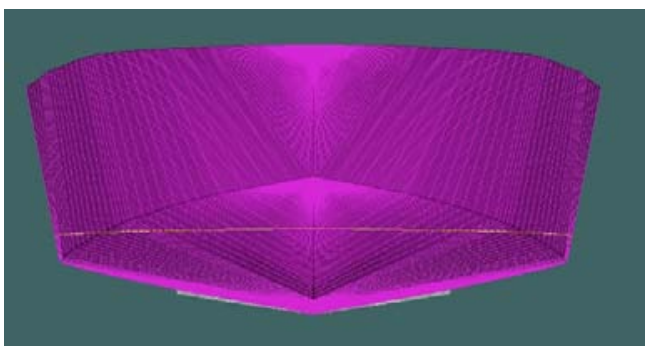

a. Deadrise, $\beta=10^{\circ}$

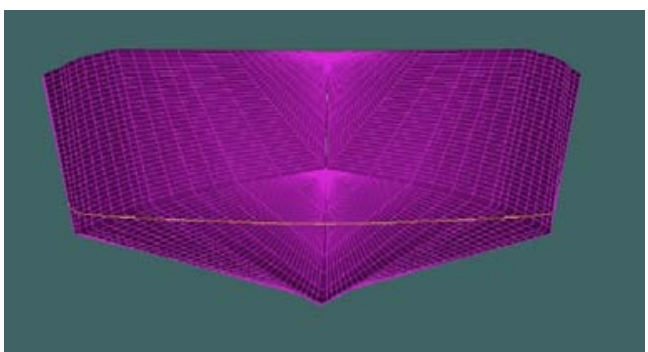

b. Deadrise, $\beta=13^{\circ}$

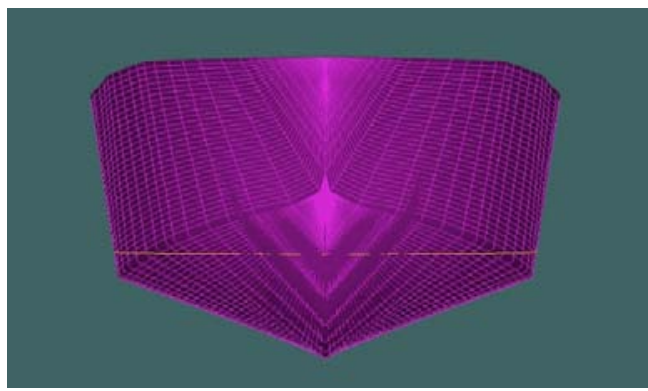

c. Deadrise, $\beta=18^{\circ}$

Gambar 5. Model 3D dengan 3 variasi deadrise, $\beta$

Tabel 6. Perbandingan ukuran pokok model kapal

\begin{tabular}{ccccc}
\hline Item & Satu an & $10^{\circ}$ & $\begin{array}{c}13^{\circ} \\
\text { (exsisting) }\end{array}$ & $18^{\circ}$ \\
\hline $\mathrm{LWL}$ & $\mathrm{m}$ & 23,700 & 23,800 & 23,900 \\
\hline $\mathrm{T}$ & $\mathrm{m}$ & 0,900 & 1,100 & 1,300 \\
\hline $\mathrm{B}$ & $\mathrm{m}$ & 6,800 & 6 & 5,200 \\
\hline $\mathrm{S}$ & $\mathrm{m}^{2}$ & 148 & 139 & 131 \\
\hline $\mathrm{Cb}$ & - & 0,539 & 0,526 & 0,504 \\
\hline $\mathrm{Cm}$ & - & 0,663 & 0,651 & 0,622 \\
\hline $\mathrm{B} / \mathrm{T}$ & - & 7,500 & 5,800 & 4,100 \\
\hline $\mathrm{VCG}$ & $\mathrm{m}$ & 0,351 & 0,426 & 0,560 \\
\hline $\mathrm{LCG}$ & $\mathrm{m}$ & 11,168 & 11,238 & 11,014 \\
\hline & & & &
\end{tabular}

Pembuatan model kapal 3D dilakukan dengan bantuan software Maxsurf Modeler. Terdapat dua tambahan variasi deadrise $\beta$ yaitu $10^{\circ}$ dan $18^{\circ}$. Untuk mengetahui efek pengaruh deadrise terhadap stabilitas dan seakeeping maka displacement kapal dibuat tetap. Model 3D dengan 3 variasi deadrise dapat dilihat pada Gambar 5.

Agar displsement kapal tetap, maka ada beberapa perubahan pada ukuran pokok kapal. Perbedaan tersebut dapat dilihat pada Tabel 6 .

\section{Perhitungan Stabilitas Kapal: 1. Software Maxsurf Stability; 2. Metode Krylov}

Perhitungan stabilitas kapal dilakukan dengan menggunakan software Maxsurt Stability. Perhitungan dengan menggunakan Maxsurf Stability membutuhkan model kapal 3D, titik berat vertikal dan horizontal dan kondisi pembebanan. Hasil perhitungan ini akan dibandingkan dengan metode Krylov II.

\section{Perhitungan RAO pada Gerakan Heaving, Pitching, dan Rolling}

Perhitungan seakeeping dilakukan dengan bantuan software Maxsurf Motion. Ada beberapa data input pada perhitungan ini yaitu: kecepatan kapal, sudut heading, tinggi gelombang serta jenis spektrum gelombang. Sedangkan tipe analisis yang digunakan adalah strip theory. Dari data input akan diperoleh RAO untuk masing-masing gerakan kapal.

\section{Output Hasil Perhitungan}

Hasil perhitungan stabilitas dan seakeeping akan dianalisis dan dibahas kemudian ditarik kesimpulan pada bagian selanjutnya.

\section{HASIL DAN PEMBAHASAN \\ Analisis Stabilitas}

Nilai GZ terhadap sudut oleng kapal untuk masing-masing model kapal dapat dilihat pada Tabel 7 dan Gambar 6. Berdasarkan perhitungan stabilitas, tiga variasi model memenuhi syarat kriteria stabilitas menurut IMO dan dapat dilihat 
pada Tabel 8.

Tabel 7. Perbandingan nilai GZ tiap deadrise

\begin{tabular}{cccc}
\hline Sudut & $\begin{array}{c}\text { GZ } \\
10^{\circ}\end{array}$ & $\begin{array}{c}\text { GZ } \\
13^{\circ}\end{array}$ & $\begin{array}{c}\text { GZ } \\
18^{\circ}\end{array}$ \\
\hline $0^{\circ}$ & 0 & 0 & 0 \\
\hline $10^{\circ}$ & 0,867 & 0,638 & 0,436 \\
\hline $20^{\circ}$ & 1,442 & 0,638 & 0,436 \\
\hline $30^{\circ}$ & 1,842 & 1,490 & 1,118 \\
\hline $40^{\circ}$ & 2,096 & 1,718 & 1,372 \\
\hline $50^{\circ}$ & 2,153 & 1,796 & 1,520 \\
\hline $60^{\circ}$ & 2,060 & 1,759 & 1,575 \\
\hline $70^{\circ}$ & 1,864 & 1,627 & 1,538 \\
\hline $80^{\circ}$ & 1,594 & 1,424 & 1,421 \\
\hline $90^{\circ}$ & 1,265 & 1,167 & 1,243 \\
\hline
\end{tabular}

\section{Kurva Stabilitas Statis}

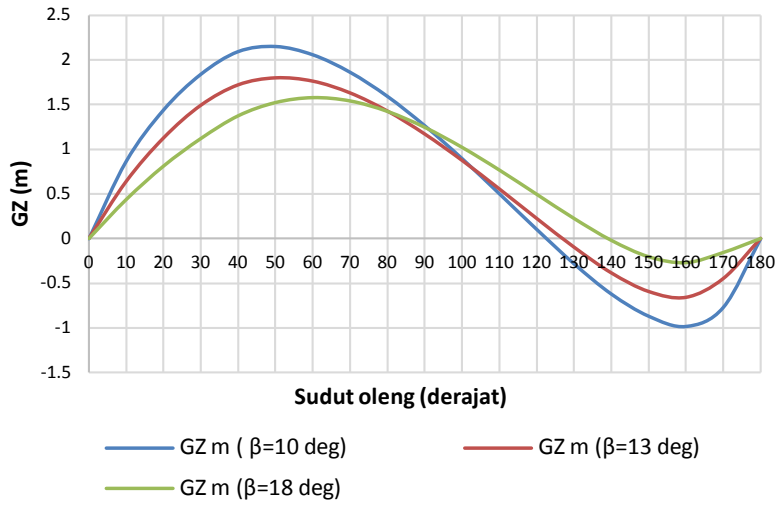

Gambar 6. Perbandingan kurva lengan stabilitas statis tiap deadrise

Dari hasil perhitungan stabilitas kapal dengan variasi sudut deadrise dapat disimpulkan bahwa sudut deadrise $10^{\circ}$ merupakan stabilitas terbaik disusul $13^{\circ}$ dan $18^{\circ}$. Hal ini terjadi karena besar sudut deadrise $10^{\circ}$ memiliki luasan lambung basah (S) lebih besar dari pada model lain meskipun pada masing-masing model memiliki displacement yang sama, karena semakin besar sudut deadrise maka nilai S semakin kecil. Selain itu, model sudut deadrise $10^{\circ}$ tersebut memiliki lebar kapal lebih besar dibandingkan model yang lain, yaitu 6,8 dan perbandingan B/T sebesar 7,5 (lihat Tabel 6).

Tabel 8. Hasil kriteria stabilitas untuk 3 model kapal

\begin{tabular}{llllll}
\hline No. & Criteria & Value & $\beta: 10^{\circ}$ & $\beta: 13^{\circ}$ & $\beta: 18^{\circ}$ \\
\hline 1. $\quad \begin{array}{l}\text { Area } 0^{\circ} \\
\text { to } 30^{\circ}\end{array}$ & $\begin{array}{c}0,055 \\
\mathrm{~m} . \mathrm{rad}\end{array}$ & 0,573 & 0,443 & 0,317 \\
\hline 2. & $\begin{array}{l}\text { Area } 0^{\circ} \\
\text { to } 40^{\circ}\end{array}$ & $\begin{array}{c}0,09 \\
\mathrm{~m} . \mathrm{rad}\end{array}$ & 0,919 & 0,725 & 0,536 \\
\hline & $\begin{array}{l}\text { Area } 30^{\circ} \\
\text { to } 40^{\circ}\end{array}$ & $\begin{array}{c}0,03 \\
\mathrm{~m} . \mathrm{rad}\end{array}$ & 0,346 & 0,282 & 0,218 \\
\hline & $\begin{array}{l}\text { Max } \mathrm{GZ} \\
\text { at } 30^{\circ} \text { or } \\
\text { greater }\end{array}$ & $\begin{array}{c}0,200 \\
\mathrm{~m}\end{array}$ & 2,156 & 1,797 & 1,575 \\
\hline & $\begin{array}{l}\text { Angle of } \\
\text { maximum } \\
\text { GZ }\end{array}$ & $25^{\circ}$ & 48,200 & 51,800 & 60,900 \\
\hline 6. & $\begin{array}{l}\text { Initial } \\
\text { GMt }\end{array}$ & 0,150 \\
$\mathrm{~m}$ & 5,230 & 3,740 & 2,525 \\
\hline
\end{tabular}

Tabel 9. Nilai GZ menggunakan metode Krylov II

\begin{tabular}{cc}
\hline Sudut & $\begin{array}{c}\mathrm{GZ} \\
10^{\circ}(\mathrm{m})\end{array}$ \\
\hline $0^{\circ}$ & 0,000 \\
\hline $10^{\circ}$ & 0,327 \\
\hline $20^{\circ}$ & 0,844 \\
\hline $30^{\circ}$ & 1,206 \\
\hline $40^{\circ}$ & 1,417 \\
\hline $50^{\circ}$ & 1,489 \\
\hline $60^{\circ}$ & 1,469 \\
\hline $70^{\circ}$ & 1,372 \\
\hline $80^{\circ}$ & 1,225 \\
\hline $90^{\circ}$ & 1,036 \\
\hline
\end{tabular}

Hasil perhitungan stabilitas model $\beta=10^{\circ}$ dengan menggunakan metode Krylov II dapat 
dilihat pada Tabel 8 dan hasil kriteria stabilitas IMO Tabel 9.

Tabel 10. Hasil kriteria stabilitas metode Krylov II

\begin{tabular}{cccc}
\hline No. & \multicolumn{1}{c}{ Criteria } & Value & $\beta: 10^{\circ}$ \\
\hline 1. & Area $0^{\circ}$ to $30^{\circ}$ & 0,055 m.rad & 0,310 \\
\hline 2. & Area $0^{\circ}$ to $40^{\circ}$ & 0,090 m.rad & 0,541 \\
\hline 3. & Area $30^{\circ}$ to $40^{\circ}$ & 0,030 m.rad & 0,231 \\
\hline 4. & $\begin{array}{l}\text { Max } G Z \text { at } 30^{\circ} \\
\text { or greater }\end{array}$ & $0,200 \mathrm{~m}$ & 1,733 \\
\hline 5. & $\begin{array}{l}\text { Angle of } \\
\text { maximum } G Z\end{array}$ & $25^{\circ}$ & 50 \\
\hline 6. & Initial $\mathrm{GMt}$ & $0,150 \mathrm{~m}$ & 5,230 \\
\hline
\end{tabular}

Perbandingan hasil perhitungan stabilitas metode Krylov dengan bantuan software dapat dilihat pada Gambar 7 berikut ini:

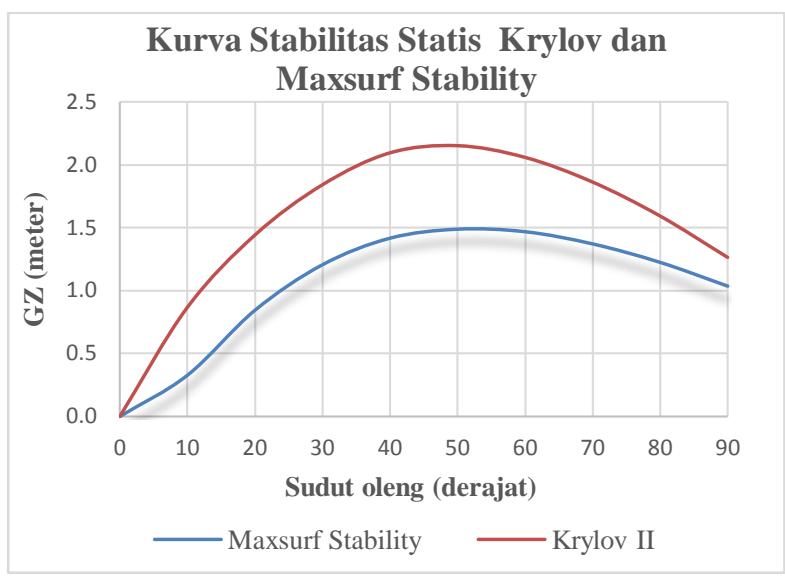

Gambar 7. Perbandingan perhitungan stabilitas kapal metode Krylov dan software Maxsuft Stability

Berdasarkan Gambar 7 dapat dilihat bahwa nilai GZ yang diperoleh dari perhitungan menggunakan software Maxsurf Stability lebih besar daripada perhitungan manual dengan menggunakan metode Krylov II. Tetapi kedua hitungan tersebut sama-sama melewati kriteria stabilitas menurut IMO.

\section{Analisis Seakeeping}

Hasil dari perhitungan gerakan kapal dibagi menjadi tiga yaitu gerakan heave, roll, dan pitch. Di mana analisis gerakan dilakukan pada heading angle, kecepatan dan sea state yang telah ditentukan sebelumnya.

\section{Gerakan Roll}

Perbandingan gerakan roll antara model kapal dengan besar sudut deadrise $10^{\circ}, 13^{\circ}$, dan $18^{\circ}$ dapat dilihat pada Gambar 8 sampai dengan Gambar 10 berikut ini:

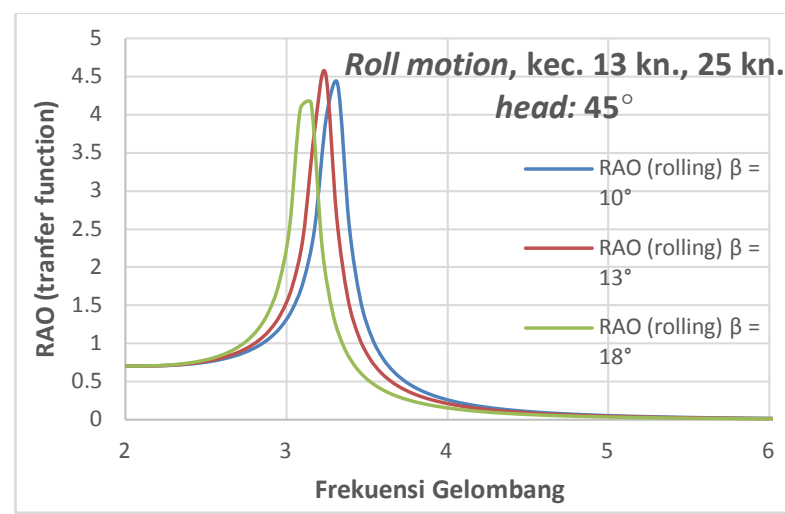

Gambar 8. Perbandingan RAO gerakan roll pada 3 model kapal dengan heading $45^{\circ}$

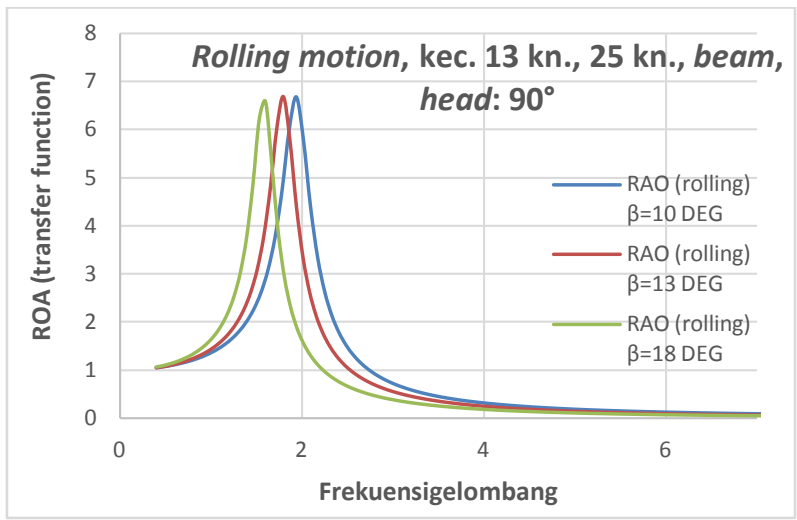

Gambar 9. Perbandingan RAO gerakan roll dengan heading $90^{\circ}$

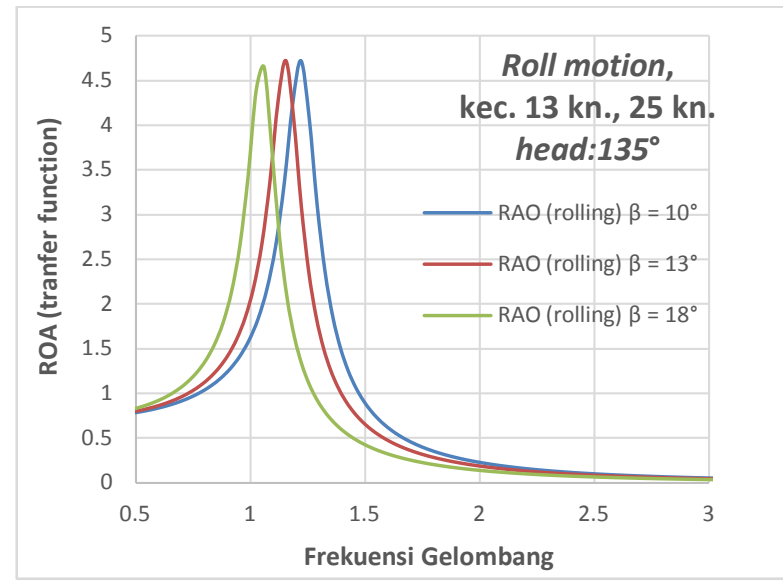

Gambar 10. Perbandingan RAO gerakan roll dengan heading $135^{\circ}$ 
Gerakan roll pada 3 model deadrise yang berbeda dapat dilihat pada Tabel 11 berikut:

Tabel 11. Amplitudo gerakan roll pada sea state 4 dan

\begin{tabular}{cccccc}
\hline \multicolumn{6}{c}{ Fr 0,84 } \\
\hline \multirow{2}{*}{$\beta$} & \multicolumn{6}{c}{ Roll pada variasi head angle (deg) } \\
\cline { 2 - 6 } & $0^{\circ}$ & $45^{\circ}$ & $90^{\circ}$ & $135^{\circ}$ & $180^{\circ}$ \\
\hline $10^{\circ}$ & 0 & 6,56 & 15,15 & 4,53 & 0 \\
\hline $13^{\circ}$ & 0 & 6,46 & 14,76 & 3,92 & 0 \\
\hline $18^{\circ}$ & 0 & 6,31 & 13,89 & 2,91 & 0 \\
\hline
\end{tabular}

Berdasarkan Gambar 8 sampai dengan Gambar 10 dapat disimpulkan bahwa gerakan roll maksimum untuk tiap model memiliki nilai yang hampir sama untuk sudut heading $90^{\circ}$ dan $135^{\circ}$. Tetapi untuk sudut heading $45^{\circ}$ RAO tertinggi berturut turut adalah model dengan sudut deadrise $13^{\circ}, 10^{\circ}$, dan $18^{\circ}$. Sedangkan untuk frekuensi resonansi (RAO tertinggi) untuk model sudut deadrise $18^{\circ}$ terjadi pada frekuensi gelombang yang lebih rendah, disusul model deadrise $13^{\circ}$ dan $10^{\circ}$. Sebagai contoh untuk sudut heading $135^{\circ}$, frekuensi resonansi terjadi pada frekuensi gelombang 1,050 , 1,150, dan 1,225 Hz untuk model dengan deadrise berturut-turut $18^{\circ}, 13^{\circ}$, dan $10^{\circ}$. Oleh karena itu dapat disimpulkan bahwa deadrise lebih berpengaruh terhadap gerakan roll, misalkan pada frekuensi rendah (periode gelombang besar) dengan demikian sudut elevasi gelombang landai, pada keadaan ini model dengan deadrise $18^{\circ}$ memiliki gerakan lebih besar dari pada model deadrise lainnya. Hal ini disebabkan karena B/T dan luas permukaan basah yang lebih kecil yang diakibatkan oleh deadrise yang besar. Karena model deadrise $18^{\circ}$ lebih responsif terhadap gelombang oleh karena itu frekuensi resonansinya lebih kecil dibandingkan model lain.

Tabel 11 dapat dilihat bahwa gerakan roll tertinggi terjadi pada model deadrise $10^{\circ}$, disusul $13^{\circ}$ dan $18^{\circ}$ untuk tiap-tiap sudut heading. Gerakan roll tertinggi pada sudut oleng $15,15^{\circ}$ pada heading $90^{\circ}$ dan model deadrise $10^{\circ}$.

\section{Perbandingan roll decay untuk} masing-masing model deadrise dapat dilihat pada Gambar 11 di bawah ini:

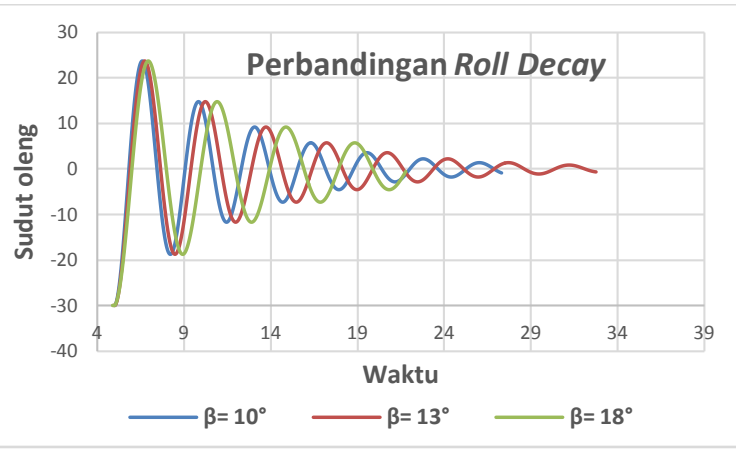

Gambar 11. Perbandingan roll decay

Roll decay pada simulasi ini dilakukan dengan sudut kemiringan kapal dibuat $30^{\circ}$ dan model kapal dilepaskan (release). Berdasarkan Gambar 11 tersebut disimpulkan bahwa model kapal dengan sudut deadrise $10^{\circ}$ memiliki natural period kecil disusul oleh deadrise $13^{\circ}$ dan $18^{\circ}$ dengan nilai berturut-turut 16,2 detik, 17,1 detik, dan 18,9 detik.

\section{Gerakan Pitch}

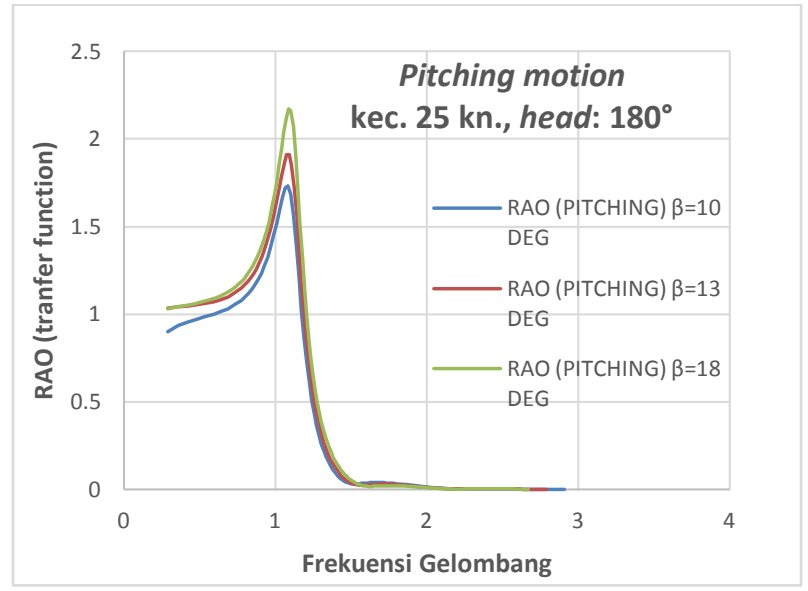

Gambar 12. Perbandingan RAO gerakan pitch

Hasil perhitungan Maxsurft Motion gerakan pitch pada masing-masing model deadrise dan sudut heading dapat dilihat pada Tabel 12 di mana gerakan tertinggi $2,93^{\circ}$ pada model deadrise $18^{\circ}$ dan heading $180^{\circ}$. Berdasarkan Tabel 12 dapat disimpulkan bahwa gerakan pitch terbesar terjadi pada model kapal dengan sudut deadrise $18^{\circ}$ dengan sudut heading $180^{\circ}$ dan diikuti oleh model 
deadrise $13^{\circ}$ dan $10^{\circ}$. Grafik RAO gerakan pitch pada sudut heading $180^{\circ}$ dapat dilihat pada Gambar 12.

Tabel 12. Amplitudo gerakan pitch pada sea state 4 dan Fr 0,84

\begin{tabular}{cccccc}
\hline & \multicolumn{4}{c}{ Pitch pada variasi head angle (deg) } \\
\cline { 2 - 6 } & $0^{\circ}$ & $45^{\circ}$ & $90^{\circ}$ & $135^{\circ}$ & $180^{\circ}$ \\
\hline $10^{\circ}$ & 2,32 & 1,01 & 1,15 & 1,94 & 2,36 \\
\hline $13^{\circ}$ & 2,26 & 0,98 & 1,25 & 2,19 & 2,61 \\
\hline $18^{\circ}$ & 2,24 & 1,03 & 1,30 & 2,48 & 2,93 \\
\hline
\end{tabular}

Berdasarkan Gambar 12 dapat disimpulkan bahwa frekuensi resonansi pada masing-masing model memiliki nilai yang hampir sama yaitu 1,175 $\mathrm{Hz}$ frekuensi gelombang. Sedangkan nilai RAO tertinggi pada model deadrise $18^{\circ}$ : 2.18 , model deadrise $13^{\circ}: 1.86$ dan deadrise $10^{\circ}: 1.72$.

\section{Gerakan Heave}

Hasil gerakan heave dapat dilihat pada Tabel 13 di mana gerakan heave paling besar adalah $0,438 \mathrm{~m}$ pada model deadrise $18^{\circ}$ dan sudut heading $180^{\circ}$. Perbandingan grafik RAO gerakan heave pada sudut heading $180^{\circ}$ dapat dilihat pada Gambar 13 berikut ini:

Tabel 13. Amplitudo gerakan heave pada sea state 4 dan Fr 0,84

\begin{tabular}{cccccc}
\hline \multirow{6}{*}{$\beta$} & \multicolumn{5}{c}{ Heave pada variasi head angle (m) } \\
\cline { 2 - 6 } & $0^{\circ}$ & $45^{\circ}$ & $90^{\circ}$ & $135^{\circ}$ & $180^{\circ}$ \\
\hline $10^{\circ}$ & 0,232 & 0,261 & 0,290 & 0,362 & 0,377 \\
\hline $13^{\circ}$ & 0,228 & 0,264 & 0,301 & 0,388 & 0,402 \\
\hline $18^{\circ}$ & 0,217 & 0,266 & 0,310 & 0,422 & 0,438 \\
\hline
\end{tabular}

Berdasarkan Gambar 13 dapat disimpulkan bahwa frekuensi resonansi pada masing-masing model memiliki nilai yang hampir sama yaitu $1,080 \mathrm{~Hz}$ frekuensi gelombang. Sedangkan nilai RAO gerakan heave tertinggi pada model deadrise $18^{\circ}$ : 2,100 $\mathrm{m} / \mathrm{m}$, model deadrise $13^{\circ}: 1,860 \mathrm{~m} / \mathrm{m}$ dan deadrise $10^{\circ}: 1,725 \mathrm{~m} / \mathrm{m}$. Jika dilihat dari nilai RAO gerakan heave ini memiliki nilai yang hampir sama dengan RAO gerakan pitch.

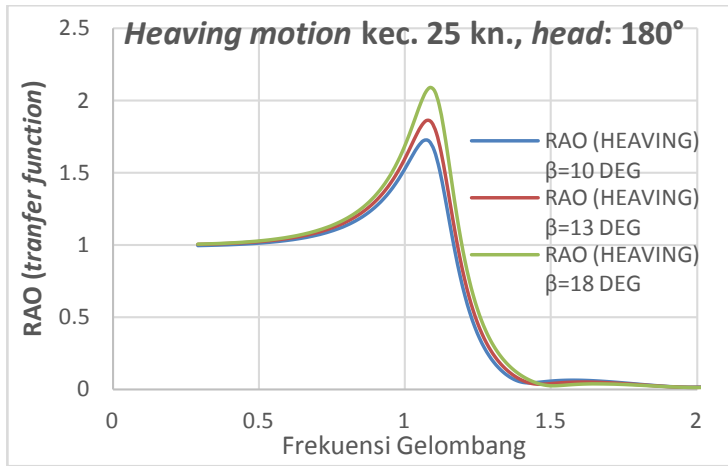

Gambar 13. Perbandingan RAO gerakan heave

\section{KESIMPULAN}

Sudut deadrise planning hull yang besar memberikan dampak negatif terhadap stabilitas. Hal ini dapat dilihat dari besar GM, luas di bawah kurva GZ dan juga kriteria stabilitas IMO. Sehingga stabilitas yang baik dihasilkan oleh model dengan deadrise $10^{\circ}$, disusul $13^{\circ}$ dan $18^{\circ}$.

Hal ini berbeda terhadap seakeeping. Sudut deadrise planning hull yang besar akan meningkatkan olah gerak kapal baik gerakan roll, pitch, dan heave. Perbedaan yang besar ditunjukkan pada gerakan roll di mana terlihat frekuensi resonansi masing-masing deadrise berbeda (lihat Gambar 10) sedangkan untuk gerakan pitch dan roll memiliki frekuensi resonansi yang sama untuk masing-masing deadrise (lihat Gambar 12 dan Gambar 13). Berdasarkan pertimbangan di atas, maka deadrise yang dipilih pada penelitian ini adalah $13^{\circ}$ dengan dasar pemilihan yaitu sudut $13^{\circ}$ memberikan stabilitas lebih baik dari $18^{\circ}$ dan juga memiliki seakeeping yang baik.

Pengaruh froude number terhadap seakeeping terjadi pada gerakan pitch dan heave. Pada sudut heading $180^{\circ}$, semakin besar froude number maka gerakan pitch dan heave lebih besar.

\section{DAFTAR PUSTAKA}

Aryawan, W. D. \& Putranto, T., 2018. The Hydrodynamics Performance of Aquaculture Fishing Vessel in Variation of Deadrise Angle 
and Sponson. International Journal of Mechanical and Production, 8(2), pp. 263-272. Blount, D. L. \& Clement, E. P., 1963. Resistance Tests of a Systematic Series of Planing Hull Forms. SNAME Transactions, pp. 491-579.

Luhulima, R. B., Setyawan, D. \& Utama, I. K. A. P., 2014. Selecting Monohull, Catamaran and Trimaran as Suitable Passenger Vessels based on Stability and Seakeeping Criteria. Kuala Lumpur, Marine Technology Centre, pp. 262-266.

Molland, A. F., Turnock, S. R. \& Hudson, D. A., 2017. Ship Resistance and Propulsion. 2nd ed. Cambridge: Cambridge University Press.

Pranatal, E., 2020. Pengaruh Sudut Deadrise terhadap Tahanan Planning Hull. Surabaya, Institut Teknologi Adhi Tama Surabaya, pp.

\section{9-655.}

Putranto, T., Suastika, K. \& Gunanta, J., 2016. Intact Stability Analysis of Crew Boat with Variation of Deadrise Angle. The 2nd International Seminar on Science and Technology, pp. 124-127.

Rawson, K. J. \& Tupper, E. C., 2001. Basic Ship Theory Volume $1 . \quad$ Oxford: Butterworth-Heinemann.

Semyonov-Tyan-Shansky, V., 1966. Statics and Dynamics of the Ship. Moscow: Peace Publishers.

Sugiyarto, S., Sulisetyono, A. \& Putranto, T., 2016. Analisis Tegangan pada Kapal Perang Tipe Corvette Akibat Beban Slamming. Jurnal Teknik ITS, 5(2), pp. G142-G147. 
HALAMAN KOSONG 